JIN Liyin

\title{
Dimensions and determinants of website brand equity: From the perspective of website contents
}

\author{
(C) Higher Education Press and Springer-Verlag 2009
}

\begin{abstract}
This study develops a research model that can be used to evaluate website brand equity from the perspective of web contents. To evaluate the model and to examine the effects of web contents on brand equity, a SEM analysis is conducted on twenty Chinese websites which could be classified into four different types. The results show that the website brand equity model, which is composed of five dimensions, namely brand loyalty, perceived quality, brand relationship, brand experience and brand attraction, is useful for measuring website brand value, and also applicable to different web types. Web contents factors, such as recourses, design, service and interactivity, are found to be the antecedents of website brand equity, and they all affect dimensions of website brand equity. However, the effects vary according to web types. The results also demonstrate that portal websites' brand equity value is the highest while shopping websites' brand equity value is the lowest among the four web types. Suggestions and implications are provided for website brand management.
\end{abstract}

Keywords brand equity, website, formation mechanism, web contents

摘要 以品牌资产和网络营销相关理论为基础, 结合本土网站品牌的内容特性, 构
建了基于消费者的网站品牌资产模型, 并通过测试四种类型的 20 个本土网站品牌对
模型进行了检验, 同时分析了网站内容因素对品牌资产的影响。研究发现: 由网站
感知质量、品牌体验、品牌吸引力、品牌关系和品牌忠诚五个变量构成的品牌资产
能较好地反映网站品牌的整体价值, 在不同类型的网站中都具有较好的适用性; 网
站资源、设计/构成、服务和互动等作为网站品牌资产前置因素的效应都得到了证实,
它们对品牌资产的影响力会随着网站类型的不同而略有变化; 所测试的本土门户网
Translated and revised from Yingxiao Kexue Xuebao 营销科学学报 (Journal of Marketing
Science), 2007, 3(3): 31-49
JIN Liyin(凶)
Department of Marketing, School of Management, Fudan University, Shanghai 200433, China
E-mail: jinliyin@fudan.edu.cn 
站的品牌价值整体较高, 而购物网站则较低, 这些结论为网站品牌资产的进一步研 究提供了理论基础, 对于本土网站的品牌管理业具有指导意义。

关键词 品牌资产, 网站, 形成机制, 网站内容

\section{Introduction}

Over the past two decades, brand equity has become one of the hot issues in the field of marketing. Abundant research has been carried out by scholars home and abroad on constitution dimensions, measurement models and influencing factors. The most representative studies include the consumer-based brand equity and the pyramid model of Keller $(1993,2001)$, the brand equity ten-element model of Aaker (1996) and the brand equity three-dimension model of Yoo and Donthu (2001).

All the extant research has contributed to building the theoretical basis for realization of the formation and effectiveness in evaluation of brand equity. However, most of the studies focus on normal product brand while fewer pay attention to the service brands and website brands. Moreover, only a few scholars have carried out research on website brand equity (Page, 2002; Loiacono, Watson and Goodhue, 2002; Nicholson and Sethi, 2002; Christodoulides and Chernatony, 2004). Up to now, this frontier subject which crosses the fields of online marketing and brand management has not drawn enough attention from scholars.

Having been produced in the virtual market environment, website brands are different from brands of traditional commodities. The influencing factors and formation mechanism of the equity value and construction process of brand equity are also different from the ones of normal commodities brands. Therefore, the equity model for normal commodities brands may not be applicable for the website brand. In recent years, with the fast expanding of E-commerce market, website brands have grown rapidly and begun to emphasize the construction of their brand equity. However, existing brand equity theories only have limited guiding significance to the Internet enterprises brands. Thus, a systematic theoretical research on website brand is needed.

Following a review of existing brand equity theories, the author combines the content characteristics of website brands to propose a web-content-based equity formation mechanism model of website brands, and empirically tests the model with 20 Chinese website brands. The purpose of the research is to enrich the theory of brand equity, as well as to offer inisghts for the brand management of online enterprises. 


\section{Literature review}

\subsection{Relevant research on brand equity}

After 1990, scholars began to research on brand equity from different perspectives, which have enriched the theories in the field while creating many different opinions. During the period, researches of brand equity mainly focused on the definition, dimensions and evaluation of brand equity. For the definition of brand equity, scholars hold diverse opinions of their own. For example, from the perspective of market performance of brand equity, Wilkie (1994) considered the increase in value of certain brands as brand equity. The brand equity based on this concept is mainly composed of financial value and profit produced by the brand, and the evaluation of brand value mainly relies on the enterprise financial data. Keller (1993) proposed the concept of "consumer-based brand equity", defined brand equity as "differential effect of brand knowledge on consumer response to the marketing of the brand". Consumer responses mainly include consumer loyalty, their resistance to competitor's marketing activities, lower price sensitivity and positive evaluations on brand extension. This comprehension of brand equity has revealed the nature of driving factors for brand equity, which has important theoretical and practical meaning. From the perspective of consumer-based brand equity, many scholars have made considerable research on the dimensions and measurement methods of brand equity. For example, Aaker (1996) has proposed a five-dimension and ten-element brand equity model, which measures brand equity by brand loyalty, perceived quality, brand association, brand popularity, and market response. The brand equity model proposed by Yoo and Donthu (2001) includes perceived quality, brand awareness/association and brand loyalty. Using the pyramid model, Keller (2001) pointed out that brand equity can be constructed following the order of brand identification $\rightarrow$ brand meaning $\rightarrow$ brand reaction $\rightarrow$ brand relation.

On the whole, research findings on brand equity have contributed to brand knowledge structure based on consumers' cognition of brand personality and formation mechanism for brand equity. However, much work has to be done concerning the problems of the practicality of certain measurement models and the causal relationships among various variables. Systematic and empirical tests of the models are also needed. For example, scholars are divided on the measurement of brand association about whether to concentrate on the association of brand's physical attributes or the social attributes or company's competitiveness. Opinions are also varied on the relationships between brand association and perceived quality. In addition, the brands in case studies are 
mainly brands of fast-moving consumer goods, and there is a lack of attention on brands of preferred and special products as well as on brands in service industries such as entertainment, communication, finance and insurance. Especially, there is a lack of academic research that focuses on website brand. With the fast expanding of E-commerce market as well as the growing of website brands, it is significant both theoretically and practically to carry out research on website brand equity.

\subsection{Website brand equity}

The development of network technologies enables the business activities of enterprises to expand from the physical world to virtual space. Website brands are different from the brands of normal products. A website brand usually goes in the form of a web address or a domain name, which symbolically implies the content of service, the type of information and resource, the quality of its service and so on. According to website functions, the website brand can be categorized into two groups, namely "derivative website brand" and "pure website brand". Derivative brand, as suggested by name, is the derivation of a certain brand, which includes the website of a normal brand (e.g., the website of a manufacturer) and the brand of a normal product named after a certain website brand (e.g., Yahoo DVD). The pure website brand refers to the website which mainly offers online information, resources, experience as well as shopping, entertainment or communication services. As for the latter one, the major goal of its operation lies in attracting more visitors, extending their visiting time, increasing click-through rates, inducing visitors to purchase more paid resources or click more frequently on the advertisement or other links on the website. Therefore, the major source of gains of pure website brand relies on sales of information resources, revenue on advertising and commission rates. In this article, the author tends to focus on pure website brands.

As for the website brand equity, there is no widely accepted definition. Existing research findings mostly concentrate on the online brand building of certain products and on-line shopping websites (Chrisodoulides and Chernatony, 2004; Page and Lepkowska-White, 2002). Additionally, due to the difficulties in on-line data gathering, there has been a lack of empirical studies in this area compared to the theoretical induction studies (Page and Lepkowska-White, 2002) and case studies (Rowley, 2004).

Based on the existing definitions and the characteristics of website brand, this paper defines website brand equity as Internet users' knowledge of certain brand names of websites in the context of virtual online market as well as the induced cognition, attitudes and responses of the websites. Due to the special nature of 
website brands, the existing findings tested with normal products may not be applied to the valuation of website brand equity. First, the 4Ps marketing mix is supposed to be of great importance in the development of brand equity, and investment and efforts that companies put in advertising, place, promotion, product and quality are considered as the significant influencing factors of brand equity of a certain product (Yoo, Donthu and Lee, 2000; Berry, 2000). However, marketing practices of website companies are quite different in terms of specific tactics. For example, the major concerns for them are click-through rates rather than sales rates, consumer (or member) conversion rates rather than market share, and online word-of-mouth communications among visitors rather than traditional advertising propagandas based on mass media. Therefore, in constructing a brand equity of a website, traditional marketing mix of 4Ps may not acquire satisfying outcome, while certain factors of website contents, such as "interaction between visitors and websites", "website design", "attributes of provider", "attributes of product or service" and the like, may have closer links to the equity of website brand (Page and Lepkowska-White, 2002). These four factors focused on online shopping websites are brought up by Page and Lepkowska-White (2002), among which the latter two factors may not be applied to non-transactional entertainment websites or community websites.

In comparison, the composite elements of website brand which are different from those of normal products are more comprehensive, as brought up by Christodoulides and Chernatony (2004). Based on expert interviews, the two authors suggested that there are ten elements in constructing website brand equity, namely online brand experience, interactivity, customization, relevance, website design, consumer service, order fulfillment, quality of brand relationships, communities and website logs. They also concluded that the ten elements are useful not only in the assessment of website brand equity, but also in the measurement of total brand equity of a normal product both in real and virtual markets if combined with the ten elements of normal product's brand equity by Aaker (1996). Although the ten elements are relatively more comprehensive, there is still overlapping and lack of distinct causal relationships among different elements. And due to insufficient data from empirical studies, the theoretical findings have some restrictions in practical application. In the following studies, they developed a set of scales that can be used to measure the website brand equity mainly focusing on the online retailers and service providers, which included 12 items of measurement representing the five dimensions of brand equity of website, namely emotional connection, online experience, responsive service nature, trust and fulfillment (Christodoulides et al., 2006).

Additionally, recent research findings in this field can be represented by explorative studies on brand personality of website by Chen and Rodgers (2006) 
as well as empirical studies on the relationships among brand experience, familiarity, satisfaction, and trust of website by Ha and Perks (2005). Without focusing on the website brand equity, some of the conclusions still shed light on the construction of website brand equity model and the exploration of dependent variables influencing the value of website brand. Based on the review of existing research findings concerning different attributes of website contents, the dimensions of website brand equity and antecedent variables could be proposed as follows.

Based on the research by Christodoulides and Chernatony (2004) and Christodoulides et al. (2006), we consider five elements, namely brand experience, perceived quality, brand attractiveness, and brand loyalty, as the core elements of website brand equity. In studies related to the measurement of brand equity, the widely accepted dimensions are perceived quality, brand cognition or association and brand loyalty, and research findings can also be seen in terms of brand relationships, identification, image, trust, preference, resonance, as well as attitudes toward brands (Mackay, 2001). Different understandings of the composite dimensions of brand equity lead to the coexistence of varied measurements. Therefore, the brand manager of a company should find out one or more proper plans among various measurement models and approaches according to the characteristics of the industry and market position. Researchers working on brand studies should also strike a better balance between general applicability and diversity. The five-element model of brand equity in this article is based on such concerns. Among the five elements, perceived quality, brand relationships and loyalty can be found in many related articles, among which the perceived quality can be associated with "fulfillment" and "trust" which can be interpreted as the perceived process and outcome of website resource delivery by net users when accessing a website as an overall evaluation of the product, information and service quality of the website. Corresponding to "emotional links" and "brand relevance", brand relationships can be termed as the perceived correlation between consumers and website brand including links both emotionally and functionally (Christodoulides and Chernatony, 2004). As a widely accepted important composite factor of brand equity for both normal products and websites (Page and Lepkowska-White, 2002), brand loyalty helps to create a regular group of consumers for the websites, and the value of website brand is mainly determined by its active online community initiatives, continuous accesses and purchases as well as the positive word-of-mouth.

Brand attractiveness and brand experience are developed on the basis of intrinsic attributes of website brand distinct from those of normal products, which can be evaluated by the indicator of "website logs" by Christodoulides and Chernatony (2004) and, to some extent, stands for the reputation and source of 
consumer of the website. Brand experience or online experience can be found in almost all literatures in this field (Christodoulides et al., 2006; Ha and Perks, 2005; Page and Lepkowska-White, 2002; Rowley, 2004). It is because that what the consumer wants from a website is not only the information, resource and service, but also a good experience at the same time (Ha and Perks, 2005). Therefore, experience is supposed to be an indispensable element of a website brand, or to be more exact, the brand of a website itself can be interpreted as a kind of experience (Dayal et al., 2000). The first goal of a website is to attract more people to visit and make them browse for longer time. The attractiveness of a website brand is the important prerequisite for maintaining the access rates, while the experience on that website will be decisive in prolonging their retention time. Once the website attracts lot of visitors and offers them great experiences which make them feel deeply absorbed, good chances are that the consumers will register in the website and become their member, and hence satisfaction and trust for the website which finally lead to loyal consumer (Ha and Perks, 2005).

Moreover, we conclude that the antecedents of website brand equity are consisted of four variables, namely website resource, design, service and interactivity, which basically cover the core contents of a website and can be applied to most websites of different types. Among them, website design and interactivity are mentioned in the research findings by Page and Lepkowska-White (2002) and by Christodoulides and Chernatony (2004). Resources of a website include both tangible products and intangible services by the provider and various digital information resources, containing the attributes of product/service by Page and Lepkowska-White (2002). Corresponding to the consumer service and personalization by Christodoulides and Chernatony (2004), website service includes attitudes toward consumers, care and respect for consumers, ways and speed of dealing with problems and personalization of services, etc.

\section{Hypotheses development}

Based on literature review above, we propose a website brand equity model (see Fig. 1). Brand equity of a website is consisted of five dimensions, namely the perceived quality, brand attractiveness, experience, relationships and loyalty, which are interdependently linked by orderly causal relationships rather than parallel relationships. The four variables of website resources, design, service and interactivity are the most important antecedent factors of brand equity. The resource of the website is a complex of information, data, video and audio materials provided by the website for the visitors. As for website companies, resources are like the products of manufacturers, which in nature is the utility 


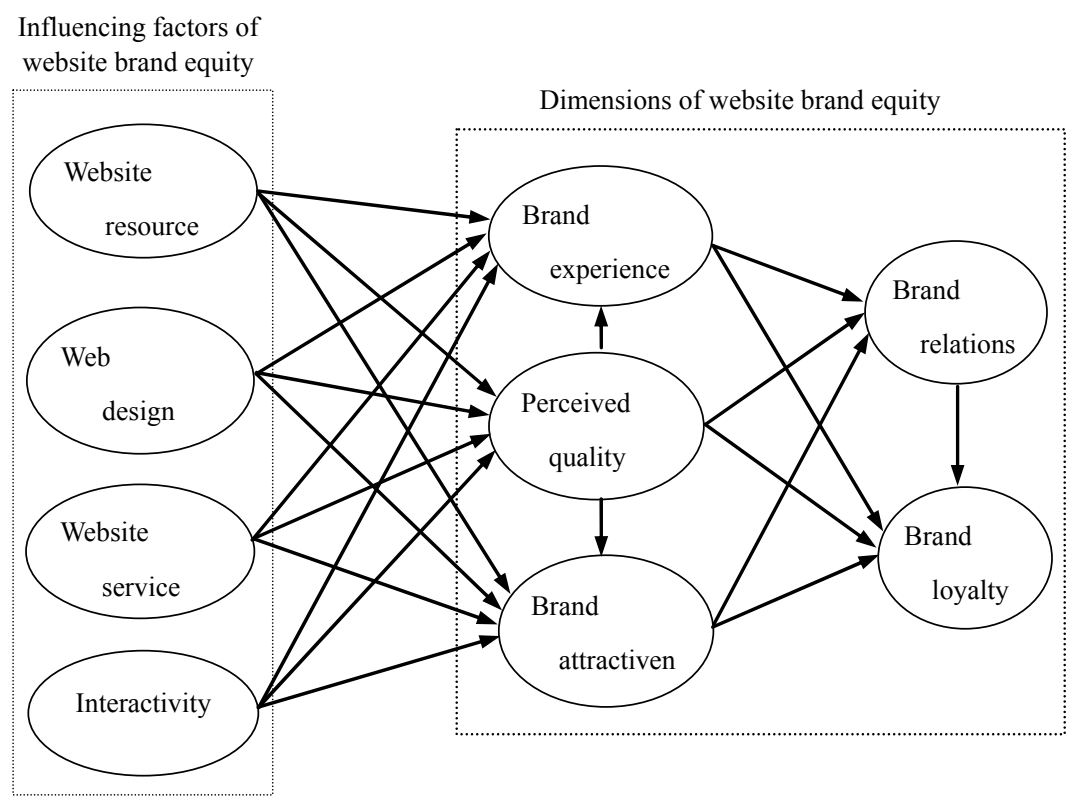

Fig. 1 Conceptual model

they offer to their consumers and, at the same time, the fundamentals for market competition. Websites with insufficient resources have little attraction for the visitors, so it is of great importance to develop accurate and differed resources with good values and rich contents as well. The resources are also important in the experience of visitors when surfing at the website in that the uniqueness, abundance and interesting points of resources will induce the excitement, curiosity, pleasure and touch of net users and hence an unforgettable experience. In addition, the capability to offer quality resources is also an important indicator in the assessment of the quality of a website by the visitors (Loiacono et al., 2002). The research findings of Palmer (2002) also supported the conclusion that net users' cognition of the overall quality of a certain website will be influenced by the quality and quantity of the website's resources. This leads to the following hypotheses:

H1a Website resources have a significantly positive effect on its brand experience.

H1b Website resources have a significantly positive effect on its brand perceived quality.

H1c Website resources have a significantly positive effect on its brand 
attractiveness.

The concept of website design includes the design of interfaces and web pages, the layout and combination of website resources, the functions of menu, the arrangement and positions of links and the application of multimedia technologies as well, which has direct impact on the cognition and perception of the website's vividness and virtual reality by the users. Proper composition and vivid interface design will enhance the users' evaluation of the website's tele-presence and their perception of its liveliness, and therefore contribute to users' pleasant experience (Shih, 1998). Just like the buildings and decorations as well as the layout and exhibition of products of a virtual enterprise, design of a website is also decisive in terms of the convenience felt by visitors when using the website's resources, which is important in forming the users' perception of the website's overall quality and image (Coyle and Thorson, 2001). This leads to the following hypotheses:

H2a Website design has a significantly positive effect on brand experience.

H2b Website design has a significantly positive effect on brand perceived quality.

H2c Website design has a significantly positive effect on brand attractiveness.

The attitudes toward and the care and respect for consumers, the responses to consumers' problems and the personalization of service can all fall into the element of website service. According to Palmer's (2002) research, direct links can be found between a website's service quality and users' evaluation of its overall quality. Cho and Leckenby (1999) also concluded in their research that the personalization of website service has a positive correlation with users' commitment possibly because the customized service will offer users unique experiences. Moreover, although website administrators only communicate with their consumers in virtual cyber spaces, their friendly attitudes and quick responses may also contribute to enhancing the website's attractiveness. Thus:

H3a Website service has a significantly positive effect on brand experience.

H3b Website service has a significantly positive effect on brand perceived quality. 
H3c Website service has a significantly positive effect on brand attractiveness.

In virtual cyberspace, consumers have to actively search for and obtain information and resource they need, and, from time to time, should play the part of creator and transmitter of information. Therefore, it is of great importance to empower consumers in searching, obtaining and creating information and attracting them to actively participate in the website's marketing activities in order to realize the positive interaction between visitors and websites as well as among different visitors (Hoffman and Novak, 1996). Users will give positive evaluation to websites that offer them effective tools, approaches or spaces so that they can enjoy convenient exchanges of resources, information and feedbacks with other users and administrators as well which leads to high level of satisfaction with the website (Liu and Shrum, 2002). Pleasant interaction with others on the website will also help to create novel and interesting experience of users in that they will find the ones with higher quality of interactions more attractive and then form a positive attitude toward the websites' brands (Cho and Leckenby, 1999). Therefore, we presume that:

H4a Website interactivity has a significantly positive effect on brand experience.

H4b Website interactivity has a significantly positive effect on brand perceived quality.

H4c Website interactivity has a significantly positive effect on brand attractiveness.

As a widely accepted important dimension of brand equity (Keller, 2001; Yoo et al., 2000), brand's perceived quality refers to the subjective evaluation of brand's overall utility by consumers. From the evolutionary perspective of relationships among different dimensions of brand equity, it is obvious that perceived quality serves as an antecedent driving factor of other dimensions such as brand relationships and loyalty. For example, the higher the perceived quality of a brand, the more possible a good impression and positive response it will have from the consumers. In cyber space, most products, services or resources exist in the form of pictures, audio and video materials and digital documents. As a result, consumers' perception of website quality will have decisive impact on constructing brand equity of a website company in this virtual world (Loiacono 
at el, 2002). Quality website will offer their users more attractive and satisfying experiences so that users are more likely to give positive evaluations and more willing to develop long-term relationships. All of the above lead to the following hypotheses:

H5a Perceived quality of a website brand has a direct positive effect on brand experience.

H5b Perceived quality of a website brand has a direct positive effect on brand attractiveness.

H5c Perceived quality of a website brand has a direct positive effect on brand relationships.

H5d Website brand perceived quality has direct positive effect on brand loyalty.

Rather than selling products or services, most websites offer their users a kind of experience, a mix of excitement, curiosity, touch, and adventures. Therefore, as for the website brand, the capability of offering its consumers great experience is an important measuring stick in the evaluation of its brand equity, and consequently brand experience should be considered as an indefensible composite dimension of brand equity. Obviously, those brands that can give their visitors pleasant experiences are more likely to have the users relied on them, and in turn, visitors to those websites will have higher level of brand loyalty. That comes down to the following hypotheses:

H6a Website brand experience has a direct positive effect on brand relationships.

H6b Website brand experience has a direct positive effect on brand loyalty.

Other important indicators when evaluating a website brand are the access rate and retention time of visitors. Considered that the brand attractiveness of a website is an important prerequisite of maintaining access rate and prolonging retention time, we suggest the attractiveness of a website brand as another composite dimension of brand equity of a website. Brand attractiveness is the capability of a website company to induce its users to access the website more frequently and for longer time. Attractive websites are those that are able to offer their users a certain utility and value in need. The attractiveness of a website brand can form kind of attachment of their users and hence a relatively higher 
usage rate. Therefore, we predict that:

H7a Website brand attractiveness has a direct positive effect on brand relationships.

H7b Website brand attractiveness has a direct positive effect on brand loyalty.

Once the long-term relationships between companies and consumers are developed, websites can make full use of personal information provided by the users to carry out effective consumer relationship management. For example, the websites can customize information, resources or services according to the preferences of their consumers, and improve their service quality as well as explore new resources based on suggestions and advice of consumers (Naudé and Buttle, 2000), which will be conducive to the enhancement of users' satisfaction and loyalty to those websites. Thus:

H8 Website brand relationships have direct positive effects on brand loyalty.

\section{Method}

\subsection{Website brand choosing and data gathering}

The study is mainly aimed at Chinese website brands which provide online information, resources and services including online shopping websites, with an exclusion of derivative websites. A lot of brands can fall into this category and are varied in terms types, awareness and influences. In order to pick out the representative ones, we divided various websites into four categories according to the resource of the websites, which, respectively, are portal websites, websites mainly offering entertainment resource services (including music, films, video games, etc., referred to as entertainment websites), websites mainly offering communication services such as community and chatting services (referred to as communication websites) and websites that focus on online transaction services (B2C mode, referred to as shopping websites). Based on the analysis of different categories of websites, we chose 10 representative cases and 40 well-known brands to carry out pre-test.

Pre-test aimed at 100 college students in Beijing who are frequent-net-users. Respondents were asked to categorize 40 website brands from their own points of view (into a total of four groups), and finally select the top 5 brands which in their opinions can best represent each category. Based on the analysis of pre-test, we 
decided to choose 20 website brands as the subjects of tests, 5 brands for each group.

Data gathering was carried out by a professional market research company in Beijing through an online survey. A collection of samples was formed based on the random panel sampling in the company's database, and then an inviting email was sent to each sample. Respondents were supposed to visit the online survey website by clicking on the links in the email and fill out the questionnaires online. As a reward, those who completed the forms received some credits which enabled them to access some of the paid resources on the website free of charge.

At first, the online survey system would discriminate from various respondents. Those who have accessed one certain website in the past 6 months could fill out one questionnaire focusing on that certain website. For those who have accessed more than one website should complete one questionnaire concentrating on one certain brand randomly selected by the system. And for those who haven't accessed any of the 20 websites, the system will automatically end their responses. When cumulative responses of 40 for questionnaire of a certain brand have been collected, the system will automatically terminate the sampling of its questionnaires. And the whole online survey will be brought to a halt when all the questionnaires of 20 brands are finished.

The process of online survey had a total response of 800 for 20 websites brand of 4 categories $(20 \times 40)$. All of the 800 questionnaires were selected randomly and were absolutely completed, which would serve as valid samples for data analysis. Demographic characteristics of samples are as follows: $58.2 \%$ are male; $88 \%$ are below 40 years old. As for the educational background, $77.5 \%$ have a three-year diplomat or above. $68.5 \%$ have a monthly salary of less than 2500 Yuan RMB. The average time they spend online is 13.7 hours, and among them, those who frequently access portal, entertainment, communication and shopping websites take up $92.6 \%, 73.9 \%, 58.1 \%$, and $41.7 \%$ respectively, and the weekly average access times are $14.5,13.8,11.4$, and 5.6 for each category. Consistent with relative existing research findings on Chinese Internet usage, these indicators can properly reflect on the structure and characteristics of Chinese Internet users.

\subsection{Questionnaire design}

The questionnaire adopted in this study consists of 4 parts. Items in the first part are designed to draw a general picture of the overall characteristics of respondents, about their familiarity, access motivation, click-through rate, retention time concerning the certain website. The major concerns in the second part are respondents' evaluations of resources, design, services and interactivity 
of certain websites. Questions in the third part mainly focus on respondents' cognition of website's perceived quality, brand experience, attractiveness, relationships and loyalty. And the last part includes items concerning demographic indicators such as gender, age and educational backgrounds, etc.

Items to use to measure variables are developed based on the review of existing literature. The measuring of website resource adopted the items that from the 5 aspects of abundance, uniqueness, usefulness, accuracy and timeliness by Palmer (2000) and Loiacono, Watson and Goodhue (2002). Based on slight revision of items suggested by Coyle and Thorson (2001), the measuring of website design/composition covers 4 dimensions of the interface liveliness, rationality of composition, simplicity in operation and the application of multimedia technologies. The measuring of website service takes advantage of 4 items suggested by Liu and Shrum (2002). And the measuring of interactivity are based on the 4 items of easy communication, quick responses, accurate feedbacks, communication methods and satisfaction of space by Hoffman, Novak and Yung (2000) and Palmer (2002).

The 4 items used to measure perceived quality come from the research by Yoo and Donthu (2001). Based on the studies by Hoffman and Novak (1996) and by Nicholson and Sethi (2002), the 4 items of novelty, excitement, abandonment, and pleasure in an experience are introduced in the measuring of brand experience. Moreover, we used 4 items of access rate, retention time, priority of access and access volume to measure brand attractiveness. Items used in the measuring of brand relationships are taken from articles by Aaker and Joachimsthaler (2000). And 3 items in the measurement of brand loyalty also referred to the studies by Yoo, Donthu and Lee (2000).

In order to guarantee the quality of variable measurement, based on the characteristics of Chinese website brands, we properly revised and readjusted the Chinese expression of various indicators and then asked 30 marketing experts to participate in the pre-test of this part. And a final version of questionnaire was developed on the basis of analyzing the experts' responses with several slight revisions. All the items above are given in a 7-point Likert Scale designed to measure the respondents" attitudes toward each item, in which " 1 " stands for completely disagree, " 4 " for neutral, and "7" for completely agree.

\section{Data Analysis}

\subsection{Reliability and validity of variable measurement}

We carried out explorative factor analysis of all samples. It shows that all the 37 
items influx as 9 valid factors with eigenvalue above 1 . Yet, two items were rejected due to cross loading, which are used to measure brand experience and brand relationship.

In order to prove the cross-category validity of the 9 factors and loaded items, we divided the total samples into 4 groups (200 in each group) and carried out explorative factor analysis separately. It shows that all sub-groups have 9 valid factors, yet among which 3 items are rejected due to lack of cross-category consistence, namely the uniqueness of resources in testing the resources of websites, the satisfaction with communication method and space in testing the interactivity and the volume of access in testing brand attractiveness. At the end of this test, the original 37 items used to measure the 9 factors have been purified into 32 items (See Table 1).

Table 1 Results of reliability and validity analysis

\begin{tabular}{|c|c|c|c|c|}
\hline $\begin{array}{l}\text { Concept } \\
\quad \text { (latent } \\
\text { variables) } \\
\end{array}$ & Measuring items & $\begin{array}{c}\text { Unstandardized } \\
\text { coeffiecient }\end{array}$ & $\begin{array}{r}\text { Standa-rdized } \\
\text { coeffic-ient }\end{array}$ & $T \quad$ Alpha \\
\hline \multirow[t]{4}{*}{ Web resource } & It is rich in resource & 1.00 & 0.727 & - \\
\hline & I can always find the latest resource & 1.122 & 0.761 & 19.8830 .874 \\
\hline & It has accurate resource & 0.967 & 0.645 & 17.650 \\
\hline & $\begin{array}{l}\text { I find the resource of this website } \\
\text { very useful }\end{array}$ & 0.985 & 0.703 & 18.212 \\
\hline \multirow[t]{4}{*}{$\begin{array}{l}\text { Web } \\
\text { design }\end{array}$} & $\begin{array}{l}\text { It has vivid interface and beautiful } \\
\text { page design }\end{array}$ & 1.00 & 0.728 & - \\
\hline & $\begin{array}{l}\text { It has reasonable arrangement of } \\
\text { resources which makes it easy } \\
\text { to find what I want }\end{array}$ & 0.891 & 0.624 & 15.6270 .912 \\
\hline & $\begin{array}{l}\text { The operation of functions is easy } \\
\text { to catch }\end{array}$ & 0.906 & 0.640 & 16.334 \\
\hline & $\begin{array}{l}\text { The application of multimedia } \\
\text { technologies is satisfying }\end{array}$ & 1.045 & 0.741 & 17.780 \\
\hline \multirow[t]{4}{*}{ Web service } & $\begin{array}{l}\text { The staff cares about consumers' } \\
\text { problems }\end{array}$ & 1.00 & 0.836 & 一 \\
\hline & It shows respect to consumers' need & 1.074 & 0.840 & 18.718 \\
\hline & It has customized service for users & 0.836 & 0.678 & 14.0230 .889 \\
\hline & The staff is very friendly & 0.937 & 0.767 & 16.834 \\
\hline \multirow[t]{3}{*}{ Interactivity } & $\begin{array}{l}\text { It's easy to communicate with } \\
\text { other users or administrators }\end{array}$ & 1.00 & 0.758 & - \\
\hline & $\begin{array}{l}\text { They have quick responses to my } \\
\text { suggestions and questions }\end{array}$ & 0.795 & 0.647 & 13.6440 .895 \\
\hline & $\begin{array}{l}\text { It has accurate quick responses to } \\
\text { information }\end{array}$ & 0.831 & 0.685 & 13.979 \\
\hline
\end{tabular}




\begin{tabular}{|c|c|c|c|c|}
\hline \multirow[b]{2}{*}{$\begin{array}{l}\text { Concept } \\
\text { (latent } \\
\text { variables) }\end{array}$} & \multicolumn{4}{|r|}{ (Continued) } \\
\hline & Measuring items & $\begin{array}{l}\text { Unstandardized } \\
\text { coeffiecient }\end{array}$ & $\begin{array}{c}\text { Standa-rdized } \\
\text { coeffic-ient }\end{array}$ & Alpha \\
\hline \multirow[t]{4}{*}{$\begin{array}{c}\text { Perceived } \\
\text { quality }\end{array}$} & $\begin{array}{l}\text { It offers trustworthy resource or } \\
\text { service (product) }\end{array}$ & 1.00 & 0.810 & - \\
\hline & $\begin{array}{l}\text { It offers quality resource or } \\
\text { service (product) }\end{array}$ & 0.988 & 0.739 & 15.577 \\
\hline & $\begin{array}{l}\text { It offers stable and reliable } \\
\text { resource or service (product) }\end{array}$ & 1.087 & 0.815 & 17.8200 .927 \\
\hline & $\begin{array}{l}\text { On the whole, it has high level of } \\
\text { overall service quality }\end{array}$ & 0.926 & 0.796 & 15.176 \\
\hline \multirow[t]{3}{*}{ Experience } & $\begin{array}{l}\text { I feel novel and interesting when } \\
\text { browsing the page }\end{array}$ & 1.00 & 0.683 & - \\
\hline & It's exciting to visit this website & 0.864 & 0.606 & 11.5750 .846 \\
\hline & $\begin{array}{l}\text { Surfing on this website is a } \\
\text { pleasant experience }\end{array}$ & 1.203 & 0.721 & 16.328 \\
\hline \multirow[t]{4}{*}{$\begin{array}{l}\text { Brand } \\
\text { attraction }\end{array}$} & $\begin{array}{l}\text { A lot of stuff attracts me to visit } \\
\text { this website }\end{array}$ & 1.00 & 0.757 & - \\
\hline & $\begin{array}{l}\text { It has a unique attraction which } \\
\text { makes me spend a lot of time } \\
\text { on the website }\end{array}$ & 0.923 & 0.714 & 14.3520 .868 \\
\hline & $\begin{array}{l}\text { Among many others, I always go } \\
\text { to visit this website first }\end{array}$ & 0.876 & 0.712 & 13.678 \\
\hline & I get used to life with this website & 1.00 & 0.622 & - \\
\hline \multirow{4}{*}{$\begin{array}{l}\text { Brand } \\
\text { Relationship }\end{array}$} & I'd like to offer my personal & 1.134 & 0.780 & 14.141 \\
\hline & information for its development & & & \\
\hline & $\begin{array}{l}\text { I'd like to become a member of this } \\
\text { website (or feel happy to do so) }\end{array}$ & 1.021 & 0.733 & 12.2800 .831 \\
\hline & $\begin{array}{l}\text { I'd like to have my own space on this } \\
\text { website (home page, blog, etc.) }\end{array}$ & 0.769 & 0.587 & 9.355 \\
\hline \multirow[t]{3}{*}{ Brand loyalty } & $\begin{array}{l}\text { It is on top of my priority list to } \\
\text { obtain information, resource } \\
\text { and service (or product) from } \\
\text { this website }\end{array}$ & 1.00 & 0.816 & - \\
\hline & $\begin{array}{l}\text { Among many other websites of } \\
\text { the same kind, I still keep the } \\
\text { access rate of this website }\end{array}$ & 0.825 & 0.729 & 11.1230 .852 \\
\hline & $\begin{array}{l}\text { I feel like a loyal consumer of this } \\
\text { website }\end{array}$ & 0.897 & 0.740 & 12.274 \\
\hline
\end{tabular}

Then we took the total sample as an example to test the reliability and validity of the 32-item measurement model. First, the Conbach's Alpha of different latent variables consisting of various items was calculated. It shows that the Alpha 
coefficients of all latent variables are significantly above the minimum of 0.70 ( $\alpha \geqslant 0.788$ ), which stands for good reliability for the measuring. Then, a confirmatory factor analysis based on AMOS 5.0 was applied to test the validity. And the results are shown in Table 1. The fitting degrees indicators of model and data are $\chi^{2}=1271.588$ (d.f. $=428, p=0.000 ; \chi^{2} / d$..$\left.=2.971\right), \mathrm{GFI}=0.901$, AGFI $=0.872$, $\mathrm{RMR}=0.069, \mathrm{CFI}=0.946, \mathrm{NFI}=0.942$, which basically reach the acceptable level. All measuring items are statistically significant on the loading coefficients of measured latent variables $(t \geqslant 9.355)$, which strongly supports the high level of convergent validity. In addition, it is also shown in Table 2 that correlation coefficients among different latent variables range from 0.212 to 0.678 with an exclusion of 1.0 in the confidence interval ( $\phi \pm 2 \mathrm{SE}$ ), which therefore proves the discriminant validity.

Table 2 Correlation coefficient matrix of latent variables

\begin{tabular}{|c|c|c|c|c|c|c|c|c|c|}
\hline & 1 & 2 & 3 & 4 & 5 & 6 & 7 & 8 & 9 \\
\hline 1. Resource & 1 & & & & & & & & \\
\hline 2. Design & 0.212 & 1 & & & & & & & \\
\hline 3. Service & 0.325 & 0.247 & 1 & & & & & & \\
\hline 4. Interactivity & 0.371 & 0.298 & 0.384 & 1 & & & & & \\
\hline 5. Perceived quality & 0.623 & 0.476 & 0.618 & 0.453 & 1 & & & & \\
\hline 6. Experience & 0.394 & 0.253 & 0.369 & 0.592 & 0.490 & 1 & & & \\
\hline 7. Attractiveness & 0.473 & 0.429 & 0.373 & 0.588 & 0.537 & 0.345 & 1 & & \\
\hline 8. Relationship & 0.309 & 0.387 & 0.429 & 0.479 & 0.638 & 0.511 & 0.431 & 1 & \\
\hline 9. Loyalty & 0.328 & 0.292 & 0.301 & 0.365 & 0.549 & 0.423 & 0.335 & 0.678 & 1 \\
\hline Mean & 5.175 & 5.260 & 4.772 & 4.863 & 5.218 & 4.685 & 4.486 & 4.532 & 4.933 \\
\hline S.D. & 1.042 & 0.986 & 1.013 & 1.106 & 0.943 & 0.982 & 0.899 & 0.985 & 0.867 \\
\hline
\end{tabular}

\subsection{Hypothesis testing}

After confirming the reliability and validity of the measurement model, we introduced the latent variables and items in Table 1 into the structural equation model in Fig. 1, and estimated the model goodness fit and each path coefficients based on the method of maximum likelihood. The model goodness fit are as follows: $\chi^{2}=1383.105\left(d . f .=437, p=0.000, \chi^{2} / d . f .=3.165\right)$, GFI $=0.907$, AGFI $=0.885$, $\mathrm{RMR}=0.061, \mathrm{CFI}=0.946, \mathrm{NFI}=0.944$, which indicates a good fitting of model to data.

Estimation of the path coefficients among different variables can be referred to Table 3. It is obvious that among the 4 content elements of a website, resource and interactivity have significant effect on perceived quality, experience and attractiveness. These results support H1a, H1b, H1c, H4a, H4b and H4c. Web Design is also significantly influencing the factors of perceived quality and attractiveness, which support $\mathrm{H} 2 \mathrm{~b}$ and $\mathrm{H} 2 \mathrm{c}$. Yet unlike the prediction in $\mathrm{H} 2 \mathrm{a}$, no significant correlation can be found between web design and experience. It is 
possibly because that as for most websites, updating network technologies and increasing attention to website design make it harder for the website to constructing its own unique attributes by design of interfaces and web pages, layout and combination of resources and application of multimedia technologies, which, to some extent, restrict the function of design in promoting website brand experience. As the visual elements rather than core content elements of a website, design is more likely to be copied by competitors, which can hardly contribute to the differentiated competitiveness. This may also be the reason why users are easily to be attracted by some delicately designed websites and speak highly of that but few of them can obtain unique and pleasant experience.

Table 3 Results of hypotheses testing

\begin{tabular}{|c|c|c|c|}
\hline Hypothesis & $\begin{array}{l}\text { Standardized } \\
\text { path coefficient }\end{array}$ & $t$-value & Results \\
\hline$\overline{\text { H1a Resource } \rightarrow \text { Experience }\left(\gamma_{11}\right)}$ & 0.118 & $2.292^{*}$ & Supported \\
\hline H1b Resource $\rightarrow$ Brand perceived quality $\left(\gamma_{21}\right)$ & 0.413 & $8.027^{* * *}$ & Supported \\
\hline H1c Resource $\rightarrow$ Attractiveness $\left(\gamma_{31}\right)$ & 0.203 & $5.079^{* * *}$ & Supported \\
\hline H2a Design/Composition $\rightarrow$ Experience $\left(\gamma_{12}\right)$ & -0.011 & -0.364 & $\begin{array}{c}\text { Not } \\
\text { supported }\end{array}$ \\
\hline $\mathrm{H} 2 \mathrm{~b}$ Design/Composition $\rightarrow$ Brand perceived quality $\left(\gamma_{22}\right)$ & 0.271 & $6.325^{* * *}$ & Supported \\
\hline $\mathrm{H} 2 \mathrm{c}$ Design/Composition $\rightarrow$ Attractiveness $\left(\gamma_{32}\right)$ & 0.208 & $5.040^{* * *}$ & Supported \\
\hline H3a Service $\rightarrow$ Experience $\left(\gamma_{13}\right)$ & 0.038 & 1.075 & $\begin{array}{c}\text { Not } \\
\text { supported }\end{array}$ \\
\hline H3b Service $\rightarrow$ Brand perceived quality $\left(\gamma_{23}\right)$ & 0.390 & $6.853^{* * *}$ & Supported \\
\hline H3c Service $\rightarrow$ Attractiveness $\left(\gamma_{33}\right)$ & 0.037 & 1.128 & $\begin{array}{c}\text { Not } \\
\text { supported }\end{array}$ \\
\hline H4a Interactivity $\rightarrow$ Experience $\left(\gamma_{14}\right)$ & 0.453 & $8.446^{* * *}$ & Supported \\
\hline H4b Interactivity $\rightarrow$ Brand perceived quality $\left(\gamma_{24}\right)$ & 0.169 & $2.895^{* *}$ & Supported \\
\hline $\mathrm{H} 4 \mathrm{c}$ Interactivity $\rightarrow$ Attractiveness $\left(\gamma_{34}\right)$ & 0.385 & $7.080^{* * *}$ & Supported \\
\hline H5a Brand perceived quality $\rightarrow$ Experience $\left(\beta_{12}\right)$ & 0.216 & $4.663^{* * *}$ & Supported \\
\hline $\mathrm{H} 5 \mathrm{~b}$ Brand perceived quality $\rightarrow$ Attractiveness $\left(\beta_{32}\right)$ & 0.114 & $2.631^{* *}$ & Supported \\
\hline H5c Brand perceived quality $\rightarrow$ Relationships $\left(\beta_{42}\right)$ & 0.463 & $10.189^{* * *}$ & Supported \\
\hline H5d Brand perceived quality $\rightarrow$ Brand loyalty $\left(\beta_{52}\right)$ & 0.186 & $5.181^{* * *}$ & Supported \\
\hline H6a Experience $\rightarrow$ Relationships $\left(\beta_{41}\right)$ & 0.250 & $5.209^{* * *}$ & Supported \\
\hline H6b Experience $\rightarrow$ Loyalty $\left(\beta_{51}\right)$ & 0.165 & $2.092^{* *}$ & Supported \\
\hline H7a Attractiveness/Charisma $\rightarrow$ Relationships $\left(\beta_{43}\right)$ & 0.195 & $3.021^{* *}$ & Supported \\
\hline H7b Attractiveness/Charisma $\rightarrow$ Loyalty $\left(\beta_{53}\right)$ & -0.017 & -0.556 & $\begin{array}{c}\text { Not } \\
\text { supported }\end{array}$ \\
\hline H8 Relationships $\rightarrow$ Loyalty $\left(\beta_{54}\right)$ & 0.532 & $14.336^{* *}$ & Supported \\
\hline
\end{tabular}

Note: ${ }^{*}$ denotes $\mathrm{p}<0.05,{ }^{* *}$ denotes $\mathrm{p}<0.01,{ }^{* * *}$ denotes $\mathrm{p}<0.001$.

Although web service is also of great importance to perceived quality of a website, little evidence can be found to prove its driving force to brand experience and attractiveness, i.e. $\mathrm{H} 3 \mathrm{~b}$ is supported while $\mathrm{H} 3 \mathrm{a}$ and $\mathrm{H} 3 \mathrm{c}$ are not. 
One possible reason is that more often than not, website requires users of active search for and creation of the information, resource and service they need, and therefore the visitors are more likely to play the dual parts of both the consumer and the producer of website resource and service. Unlike normal services, the utilization of online service requires the participation of visitors to the utmost. Most highly-involved visitors will recognize the attractiveness of the website and enjoy a wonderful experience without paying much attention to the existence of staff members of their service provider, and therefore creating a self-service impression which may weaken the perceived function of website service and hence a limited effect on brand experience and attractiveness.

The analysis of relationships among different dimensions of website brand equity shows that except for the direct impact of brand attractiveness to brand loyalty, other path coefficients suggested by the author are significant, therefore $\mathrm{H} 5 \mathrm{a}, \mathrm{H} 5 \mathrm{~b}, \mathrm{H} 5 \mathrm{c}, \mathrm{H} 5 \mathrm{~d}, \mathrm{H6a}, \mathrm{H} 6 \mathrm{~b}, \mathrm{H} 7 \mathrm{a}$ and $\mathrm{H} 8$ have all been supported. It indicates that brand attractiveness is mainly designed to induce net users to access the website. Yet visitors will not develop brand loyalty just by brand attraction. The forming of brand loyalty lies in their experience, perceived quality and brand relationships.

\subsection{Invariance test of the model}

It is necessary to test the invariance of the model in terms of its general applicability to various types of websites. Invariance test is designed to test whether the model will varied significantly among different samples, including tests on the number of variables, observation variables' load on corresponding latent variables and path coefficients among different variables (Yoo and Donthu, 2001). With reference to the test method of model's invariance by Chaudhun and Holbrook (2001), we applied the structural equation model respectively to portal, entertainment, community and online shopping website samples to test the applicability of such model in different types of websites. The results are shown in Table 4. The goodness fit of model to data of the 4 types of sample fall into the acceptable interval which implies that in terms of patterns, the model is applicable in various types of websites. Especially in the samples of portal websites, we obtained good fitting degrees and path coefficients similar to the analysis of aggregate level samples, which suggests that the model has best robustness when applied to portal websites. This also reflects the comprehensive attributes of such websites which include various service functions such as information resource, entertainment, community and online shopping as well. 
Table 4 Invariance test on model in different sample sets

\begin{tabular}{|c|c|c|c|c|c|c|c|c|}
\hline \multirow[t]{2}{*}{$\begin{array}{l}\text { Name of } \\
\text { Path }\end{array}$} & \multicolumn{2}{|c|}{$\begin{array}{l}\text { Portal website } \\
\text { samples }\end{array}$} & \multicolumn{2}{|c|}{$\begin{array}{l}\text { Entertainment } \\
\text { website samples }\end{array}$} & \multicolumn{2}{|c|}{$\begin{array}{l}\text { Community website } \\
\text { samples }\end{array}$} & \multicolumn{2}{|c|}{$\begin{array}{l}\text { Shopping website } \\
\text { samples }\end{array}$} \\
\hline & $\begin{array}{r}\text { Standardized } \\
\text { coefficient }\end{array}$ & $t$-value & $\begin{array}{r}\text { Standardized } \\
\text { coefficient }\end{array}$ & $t$-value & $\begin{array}{r}\text { Standardized } \\
\text { coefficient }\end{array}$ & $t$-value & $\begin{array}{r}\text { Standardized } \\
\text { coefficient }\end{array}$ & $t$-value \\
\hline$\gamma_{11}$ & 0.120 & $2.311^{*}$ & 0.117 & $2.198^{*}$ & 0.102 & $1.989^{*}$ & 0.124 & $2.442^{* *}$ \\
\hline$\gamma_{21}$ & 0.392 & $5.543^{* * *}$ & 0.398 & $5.732^{* * *}$ & 0.385 & $5.465^{* *}$ & 0.441 & $6.067^{* * *}$ \\
\hline$\gamma_{31}$ & 0.224 & $3.648^{* * *}$ & 0.532 & $7.930^{* * *}$ & 0.199 & $2.785^{* *}$ & 0.192 & $2.847^{* *}$ \\
\hline$\gamma_{12}$ & -0.009 & -0.197 & 0.120 & $2.235^{*}$ & 0.034 & 0.056 & -0.032 & -0.060 \\
\hline$\gamma_{22}$ & 0.288 & $3.746^{* * *}$ & 0.252 & $3.489^{* * *}$ & 0.276 & $3.124^{* *}$ & 0.249 & $3.030^{* *}$ \\
\hline$\gamma_{32}$ & 0.212 & $3.040^{* * *}$ & 0.221 & $3.170^{* *}$ & 0.196 & $2.623^{* *}$ & 0.198 & $2.773^{* *}$ \\
\hline$\gamma_{13}$ & 0.041 & 0.920 & 0.025 & 0.634 & 0.044 & 0.071 & 0.023 & 0.049 \\
\hline$\gamma_{23}$ & 0.367 & $5.531^{* * *}$ & 0.353 & $4.878^{* * *}$ & 0.112 & $2.020^{*}$ & 0.531 & $7.826^{* * *}$ \\
\hline$\gamma_{33}$ & 0.029 & 0.857 & 0.017 & 0.032 & 0.058 & 0.023 & 0.035 & 0.062 \\
\hline$\gamma_{14}$ & 0.417 & $5.373^{* * *}$ & 0.494 & $6.557^{* * *}$ & 0.634 & $8.752^{* * *}$ & 0.323 & $4.187^{* * *}$ \\
\hline$\gamma_{24}$ & 0.185 & $2.954^{* *}$ & 0.170 & $2.626^{* *}$ & 0.327 & $4.968^{* * *}$ & 0.086 & 1.203 \\
\hline$\gamma_{34}$ & 0.340 & $5.080^{* * *}$ & 0.393 & $5.634^{* * *}$ & 0.458 & $6.264^{* * *}$ & 0.125 & $2.458^{*}$ \\
\hline$\beta_{12}$ & 0.232 & $5.305^{* * *}$ & 0.225 & $4.901^{* * *}$ & 0.203 & $3.702^{* * *}$ & 0.214 & $2.895^{* *}$ \\
\hline$\beta_{32}$ & 0.157 & $2.821^{* *}$ & 0.103 & $2.130^{*}$ & 0.125 & $2.439^{* *}$ & 0.107 & $2.006^{*}$ \\
\hline$\beta_{42}$ & 0.506 & $8.189^{* * *}$ & 0.423 & $7.321^{* * *}$ & 0.457 & $7.735^{* * *}$ & 0.428 & $6.889^{* * *}$ \\
\hline$\beta_{52}$ & 0.190 & $3.014^{* *}$ & 0.177 & $2.869^{* *}$ & 0.162 & $2.610^{* *}$ & 0.185 & $2.794^{* *}$ \\
\hline$\beta_{41}$ & 0.244 & $3.679^{* *}$ & 0.338 & $4.357^{* * *}$ & 0.396 & $5.435^{* * *}$ & 0.193 & $3.120^{* *}$ \\
\hline$\beta_{51}$ & 0.157 & $2.004^{*}$ & 0.202 & $2.348^{*}$ & 0.192 & $2.754^{* *}$ & 0.131 & $2.447^{*}$ \\
\hline$\beta_{43}$ & 0.213 & $2.852^{*}$ & 0.180 & $2.250^{*}$ & 0.198 & $3.002^{* *}$ & 0.140 & $2.639^{* *}$ \\
\hline$\beta_{53}$ & 0.019 & 0.026 & -0.002 & -0.001 & 0.004 & 0.005 & -0.038 & -0.071 \\
\hline \multirow[t]{2}{*}{$\beta_{54}$} & 0.547 & $8.678^{* * *}$ & 0.518 & $7.377^{* * *}$ & 0.525 & $7.839^{* * *}$ & 0.594 & $8.135^{* * *}$ \\
\hline & \multicolumn{2}{|c|}{$\chi^{2}=452.732$} & \multicolumn{2}{|c|}{$\chi^{2}=562.419$} & \multicolumn{2}{|c|}{$\chi^{2}=622.725$} & \multicolumn{2}{|c|}{$\chi^{2}=717.554$} \\
\hline \multirow{4}{*}{$\begin{array}{l}\text { Fitness } \\
\text { of model }\end{array}$} & \multicolumn{2}{|c|}{$\chi^{2} / d \cdot f=1.036$} & \multicolumn{2}{|c|}{$\chi^{2} / d . f .=1.287$} & \multicolumn{2}{|c|}{$\chi^{2} / d . f .=1.425$} & \multicolumn{2}{|c|}{$\chi^{2} / d . f .=1.64$} \\
\hline & \multicolumn{2}{|c|}{ GFI $=0.928$} & \multicolumn{2}{|c|}{ GFI $=0.916$} & \multicolumn{2}{|c|}{ GFI $=0.905$} & \multicolumn{2}{|c|}{ GFI $=0.896$} \\
\hline & \multicolumn{2}{|c|}{ AGFI $=0.902$} & \multicolumn{2}{|c|}{ AGFI $=0.894$} & \multicolumn{2}{|c|}{ AGFI $=0.878$} & \multicolumn{2}{|c|}{ AGFI $=0.863$} \\
\hline & \multicolumn{2}{|c|}{$\mathrm{RMR}=0.049$} & \multicolumn{2}{|c|}{$\mathrm{RMR}=0.052$} & \multicolumn{2}{|c|}{$\mathrm{RMR}=0.058$} & \multicolumn{2}{|c|}{$\mathrm{RMR}=0.064$} \\
\hline
\end{tabular}

Note: ${ }^{*}$ denotes $\mathrm{p}<0.05,{ }^{* *}$ denotes $\mathrm{p}<0.01,{ }^{* * *}$ denotes $\mathrm{p}<0.001$.

In the other three sample sets, some paths coefficient estimates in the respective models have noteworthy changes. To analyze whether these changes are significant in statistics, we have conducted equality tests with the coefficient. The method is to form an equality constrained model by setting the path coefficients, which will be tested, to be completely equality in the different four samples within AMOS 5.0 program, while setting other coefficients to be free, and get $\Delta \chi^{2}$ by comparing $\chi^{2}$ differences between the equality constrained model and unconstrained model. If the $\Delta \chi^{2}$ has statistical significance, it means that, in unconstrained model, for the difference of sample sets, the changes of path 
coefficients, which has been set to be identically equal, is significant in statistics. By this procedure, we find there are 7 paths in all with significantly changed coefficients due to sample sets differences, namely resource $\rightarrow$ attractiveness $\left(\gamma_{31}\right)$, website design/composition $\rightarrow$ experience $\left(\gamma_{12}\right)$, service $\rightarrow$ perceived quality $\left(\gamma_{23}\right)$, interactivity $\rightarrow$ experience $\left(\gamma_{14}\right)$, interactivity $\rightarrow$ perceivedquality $\left(\gamma_{24}\right)$, interactivity $\rightarrow$ attractiveness $\left(\gamma_{34}\right)$, experience $\rightarrow$ relationships $\left(\beta_{41}\right)$ (See Table 5). Other variations of path coefficients are treated as insignificant because $\Delta \chi^{2}$ is below critical value.

Based on the analysis, it is obvious that the types of websites have a kind of moderated roles in certain path relationships, which mainly occurs in specialized websites such as entertainment, online shopping and community websites. First, in the test on entertainment websites samples, the relationship between website design and brand experience is statistically significant that can not be proved when tested on other sample sets. The resource $\rightarrow$ attractiveness $\left(\gamma_{31}\right)$ path coefficient is also significantly higher than that of other types of websites, indicating that physical evidence elements is important in entertainment website visitors' brand experiences and abundant entertainment resource itself has great attraction to the visitors.

Second, in the test of online shopping website samples, the impact of online service on perceived quality is significantly higher than that of other types of websites. Unlike services offered by other websites, online shopping mall provides a service package of mixed services in terms of product information, security, payment, delivery and after service items. When evaluating the quality of a website of this kind, consumers will attach greater importance to the factors of service. Third, interactivity is supposed to have greater influence in such variables as perceived quality, experience and attractiveness in community website samples. Also, the impact of brand experience on brand relationships is significant in this sample set. All the above suggests that interactivity is the core experience offered by a community website. Therefore, it is considered as the most effective way of constructing community website brand equity to enhance the quality of visitors' interactions so as to strengthen their brand experience. Conversely, in the sample set of shopping websites, interactivity plays a relatively insignificant part in forming users' perception of brand quality, and brand experience has little impact on brand relationships. Perhaps this is because that most shopping websites tend to highlight product information with a transaction-facilitating orientation rather than emphasizing shopping experiences, which implies that factors such as product information, quality of goods, prices, delivery and after service are supposed to be the core elements in constructing the brand equity of an online shopping mall. 
Table 5 Path coefficients varied among different sample sets

\begin{tabular}{cccccccc}
\hline \multicolumn{2}{c}{ Fitting indicators } & $\chi^{2}$ & $\mathrm{GFI}^{2}$ & CFI & RMR & d.f. & $\Delta \chi^{2}$ \\
\hline \multicolumn{2}{c}{ Unconstrained model } & 2355.43 & 0.895 & 0.937 & 0.062 & 437 & - \\
Equality & $\gamma_{31}$ Identical & 2367.10 & 0.889 & 0.927 & 0.069 & 440 & $11.67^{* *}$ \\
constrained & $\gamma_{12}$ Identical & 2363.94 & 0.890 & 0.930 & 0.067 & 440 & $8.51^{*}$ \\
model & $\gamma_{23}$ Identical & 2363.56 & 0.891 & 0.931 & 0.066 & 440 & $8.13^{*}$ \\
& $\gamma_{14}$ Identical & 2364.59 & 0.890 & 0.929 & 0.067 & 440 & $9.16^{*}$ \\
& $\gamma_{24}$ Identical & 2364.08 & 0.890 & 0.930 & 0.067 & 440 & $8.65^{*}$ \\
& $\gamma_{34}$ Identical & 2364.41 & 0.890 & 0.929 & 0.067 & 440 & $8.98^{*}$ \\
& $\beta_{41}$ Identical & 2365.55 & 0.889 & 0.928 & 0.069 & 440 & $10.12^{* *}$ \\
\hline
\end{tabular}

Note: ${ }^{*}$ denotes $\mathrm{p}<0.05,{ }^{* *}$ denotes $\mathrm{p}<0.01$.

\subsection{Evaluation and comparison of the tested websites' brand equity}

The modeling of website brand equity in the current study is designed to assess the intrinsic value of a website brand from the perspective of consumers so that website companies can have better understanding of the brands' position both of themselves and of competitors in consumers' minds in order to adopt specialized brand management strategies. Based on analyses above, we further carried out comparative studies and evaluation of scores by the 20 tested Chinese brands on different dimensions. Since the each dimensions of brand equity are the measurement result of various observation variables, the method of simple average as well as weighted average are available to acquire a corresponding score. Due to the insignificant difference between the results of the two methods (Yoo and Donthu, 2001), we adopted the more convenient method of simple average and the results can be seen in Table 6 .

Table 6 Ranking of scores of tested brands' equity

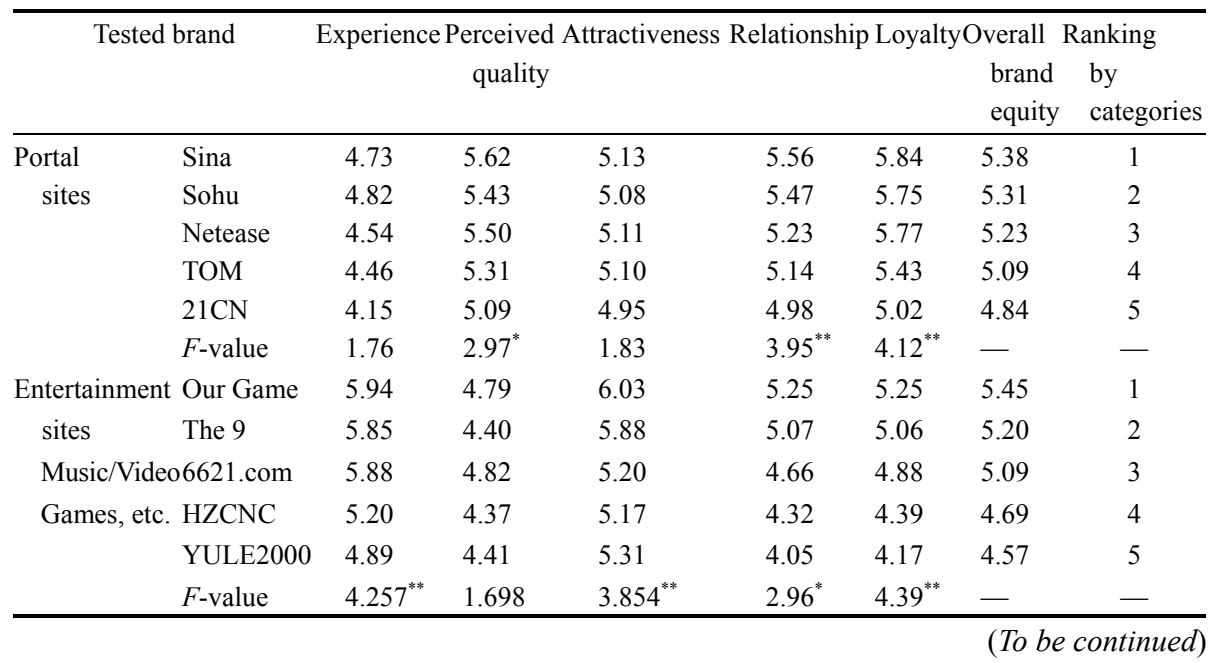




\begin{tabular}{|c|c|c|c|c|c|c|c|c|}
\hline \multirow[t]{4}{*}{ Tested brand } & \multirow[t]{4}{*}{ Experience } & \multirow{4}{*}{$\begin{array}{l}\text { Percei } \\
\text { ved } \\
\text { quality }\end{array}$} & \multirow{4}{*}{$\begin{array}{l}\text { Attracti } \\
\text { veness }\end{array}$} & \multirow{4}{*}{$\begin{array}{l}\text { Relations } \\
\text { hip }\end{array}$} & \multirow[t]{4}{*}{ Loyalty } & \multicolumn{3}{|c|}{ Overall Ranking Tested brand } \\
\hline & & & & & & brand & by & \\
\hline & & & & & & equity & catego & \\
\hline & & & & & & & ries & \\
\hline \multirow{2}{*}{$\begin{array}{c}\text { Community } \\
\text { websites }\end{array}$} & Tencent QQ & 5.31 & 5.22 & 5.07 & 4.78 & 5.30 & 5.14 & 1 \\
\hline & Mop & 5.25 & 4.83 & 4.66 & 4.84 & 5.01 & 4.97 & 2 \\
\hline BBS/ & Tianya & 5.30 & 4.65 & 4.43 & 4.65 & 4.75 & 4.76 & 3 \\
\hline Chatting/ & Xici & 5.01 & 4.23 & 4.02 & 4.50 & 4.77 & 4.51 & 4 \\
\hline Friends & Xilu & 5.09 & 4.02 & 3.86 & 4.51 & 4.32 & 5.36 & 5 \\
\hline -making, etc & $F$-value & 1.548 & $3.469^{*}$ & $5.031^{* *}$ & 1.216 & $4.357^{* *}$ & - & - \\
\hline \multirow{2}{*}{$\begin{array}{l}\text { Shopping } \\
\text { websites }\end{array}$} & Eachnet & 4.74 & 5.53 & 4.55 & 5.04 & 5.01 & 4.97 & 1 \\
\hline & Taobao & 4.83 & 5.14 & 4.58 & 4.87 & 5.32 & 4.95 & 2 \\
\hline \multicolumn{2}{|c|}{ B2C/Auction/Joyo } & 4.57 & 5.05 & 4.67 & 4.34 & 5.26 & 4.78 & 3 \\
\hline \multirow{3}{*}{$\begin{array}{l}\text { Online } \\
\text { purchasing, } \\
\text { etc }\end{array}$} & Dangdang & 4.02 & 4.67 & 4.06 & 4.22 & 5.13 & 4.42 & 4 \\
\hline & 800Buy & 4.21 & 4.18 & 3.84 & 4.10 & 4.75 & 4.22 & 5 \\
\hline & $F$-value & 2.03 & $3.970^{* *}$ & $2.541^{*}$ & $2.395^{*}$ & $2.862^{*}$ & - & - \\
\hline
\end{tabular}

Note:

1. Overall brand equity is the mean of loads for 5 factors, and the ranking is based on the overall loads.

2. $F$ is the ratio of interclass variance to intraclass variance. ${ }^{*}$ denotes $p<0.05,{ }^{* *}$ denotes $p<0.01$.

There is no significant difference among scores of 5 brands in the group of portal websites in terms of brand experience and attractiveness. Yet significant variation can be found when it comes to perceived quality, brand relationships and loyalty. It can be concluded on the basis of post hoc multiple comparisons that Sina, Sohu and Netease score higher on the dimensions of perceived quality and brand loyalty. Sina and Sohu have the highest scores in terms of brand relationships. All the above shows that as the most representative comprehensive portal websites in China, the quality of Sina and Sohu have gained wide acclaim from consumers, based on which firm link between the websites and consumers have been developed. Major differences between Netease and the top 2 lie in the aspect of brand relationships which needs to be strengthened in the future. $21 \mathrm{CN}$ scores relatively low on each dimension which implies an overall improvement of the website brand is needed.

Scores of the 5 entertainment website brands are significantly varied from each other except for perceived quality. It can be concluded from post hoc multiple comparisons of either two samples that Our Game and The 9 score significantly higher than others in terms of brand attractiveness, relationships and loyalty. In regards to brand experience, Our Game, The 9 and Yule2000 score much the same. It suggests that Our Game and The 9 are very attractive as online video game websites with a group of loyal consumers, whereas Yule2000, as a 
music website, has achieved great success in consumer brand experience management with efforts to be made in the aspect of brand relationships and consumer loyalty. The rest two, 6621.com and HZCNC score relatively lower on almost all dimensions, which mean that it is necessary for them to enrich their resource and highlight uniqueness in order to enhance the attractiveness of their brands.

The 5 brands of community websites varied significantly among the scores in terms of perceived quality, brand attractiveness and brand loyalty. It can be seen from the results of comparison that Tencent scores a lot higher than all the other brands on the three dimensions, implying a distinct strength in overall brand equity. After years of operation, Tencent has made QQ the synonym of Chinese instant messaging tools. Based on the brand equity value of QQ, Tencent can take brand extension into consideration to expand the market domain into E-commerce and virtual markets so as to obtain greater benefits.

The 5 brands of shopping websites reported significantly different scores on the dimensions of perceived quality, brand attractiveness, brand relationships and loyalty as well. Based on post hoc multiple comparisons, it is obvious that Eachnet has a distinctly high score in terms of perceived quality and yet a relatively lower score on the dimension of brand loyalty compared to that of Taobao and Joyo, indicating that efforts have to be made in consumer lock-in marketing strategies in order to increase the level of brand loyalty. Dangdang and 800 Buy score lower in regards to perceived quality and brand attractiveness which can be improved by enriching product resource and improving service quality so as to attract more visitors.

On the whole, brand equity of portal website is valued higher than that of websites of other kinds, while that of shopping website is relatively lower, and community and entertainment website stay in the middle at average level, which is in accordance with the practices in Chinese cyber market. As the comprehensive online service provider offering information, entertainment, community, shopping and search engine services, portal websites possess sufficient resources and have distinct strengths in terms of quality and service of the websites, attracting lots of visitors and owning their stable loyal consumers, with relatively higher value of brand equity. According to the latest report on China's development of Internet, among all the frequently used online services, the utilization rate for online shopping is below 25\%, far behind that of information, entertainment and community communication services, which can possibly explain partly the relatively low level of the overall brand equity value of Chinese online shopping website. 


\section{Conclusion}

\subsection{Contributions to theory}

This article constructs a website brand equity model, and for the first time, attempts to carry out empirical studies of Chinese website brands so as to prove the rationality and general applicability of the model, which contributes to the further in-depth researches in this field. Concerning the differences in dimensions of website brand equity from those of normal products and services, we attempt a theoretical combination of brand equity and online marketing in order to test of major dimensions of brand experience, attractiveness, relationships and the like. It shows that the 5-dimension model consisting of perceived quality, brand experience, attractiveness, relationships and loyalty can properly interpret the formation mechanism of website brand equity. And rather than parallel coexistence, it is the orderly causal relationships between different factors that link the 5 factors together. Among them, brand experience, attractiveness and perceived quality are the major driving force of building relationships between websites and consumers and hence an increasing level of brand loyalty.

Yet on the other hand, the traditional marketing portfolio of $4 \mathrm{P}$, including enhancing brand awareness by advertising, improving brand quality by product management, creating brand image or adjusting brand association by pricing strategies and promote brand ownership by logistic management, have limited significance in guiding the improving of website brand equity in the context of virtual world. It is mainly because that brand of website is developed in the virtual market of cyber space, and the value of the website brand is mostly influenced by the marketing variables related to the contents of the website. Therefore, we put forward 4 variables of website resource, design, service and interactivity and analyzed their functions in driving the brand equity of a website. The results of empirical studies support most of our hypotheses, which serves as the theoretical fundamentals for further studies.

Another important research finding in this article is that the impact the antecedents has on brand equity slightly varies among different types of websites. For example, as for entertainment websites, web design will influence visitors' brand experience and it is website resource that has the biggest influence. As for online shopping websites, brand equity will be most influenced by perceived quality and service, and less impacted by interactivity and experiences. However, interactivity and brand experiences are supposed to be the most important in community websites. Although it is not the major goal to explore the moderated effects of the types of websites in the current study, the findings above will help us recognize the necessity and significance of carrying out studies further based 
on current research in order to explore the different impact of influencing factors of brand equity among various types of websites.

\subsection{Implications for managers}

The findings in this study may serve as guidelines for the assessment and improvement of website brand equity. Perceived quality, experience and attractiveness are supposed to be basic driving factors in building the brand-consumer relationship, and firm relationships of brand will enhance the brand loyalty and overall brand value. Therefore, the first and foremost goal of supporting marketing activities is to improve the perceived quality of the website brand among net users, and to enhance the attractiveness and also the visitors' brand experience by providing quality online services. In this phase, companies can set specific marketing goals such as total visits, retention time, the depth of surfing, and visitors' reviews, and keep an eye on the changing trend. When the website brand is capable of attracting lots of visitors and satisfying their needs for experience, companies should make efforts to form long-term relationship with them and change them into stable loyal consumers. This requires the ".com" companies of great efforts to obtain information like demographic, lifestyle, online browsing behaviors and preferences of visitors to form a database, and then develop customized resources and online services, which can in turn create visitors' attachment to the website and finally achieve high level of brand loyalty. The number of members, repeated access rate and conversion rate of online services can be interpreted as specific goals.

Based on the brand equity model suggested in this article, managers can measure the website brand of their companies and of competitors as well, which can not only assess the improvement of marketing efforts by their own companies, but also spot the market position, diagnose the existing problems, understand the differences from competitors, and then make clear of the efforts to be made. Additionally, this article also provides operational method to develop brand equity in the context of virtual cyber market. First, content resource is the core element of the quality, attractiveness, and experience of a website, and therefore improving the management of website resource serves as the basis for creating website brand values, which can be acquired by guaranteeing the website's advantages in resources in terms of abundance, timeliness, usefulness and accuracy. Second, website design has influence in website attractiveness and perceived quality as well. As a result, rather than ignore the visual element of their websites, managers should rationalize the arrangement of resources, simplify the function of menu and at the same time introduce the application of multimedia technologies to keep the delicate and vivid design in interfaces and 
web pages. Third, perceived quality will be greatly influenced by web service. Commonly, there is very little chance for staff members of a website and website visitors to meet. Therefore, the encounters with website administrators in virtual cyber space will have decisive impact on consumers' evaluation of online services. Managers, in turn, should pay special attention to this kind of service contact in cyber space, caring for consumers and respecting their suggestions, making quick responses to their inquiry, and meanwhile developing personalized online services. Fourth, interactivity plays an important part in creating high level of perceived quality, attractiveness and brand experience. Managers can improve the quality of users' interactivity by providing communication tools and space, encouraging information exchange between the website and the users and offering them an interactive community for their online communications.

As suggested by the findings in the article, website companies should tell differences among the types of websites in their operations. For example, shopping websites are supposed to emphasize promoting the service quality in terms of product information, quality of goods, prices, delivery and after service, community websites however should attach greater importance to the investment in online interactivity and experiences, while entertainment websites should devote themselves to the exploration of entertainment resources and improvement in tele-presence.

Moreover, we also find that brand value of Chinese portal websites are above the average level, and basically brand value of shopping websites are relatively lower than that of other types of websites, while community and entertainment websites stay in the middle, which, in a sense, reflects on basic characteristics of Chinese Internet users in their utilization of online resources. As for the advantageous portal websites, it is feasible either to take advantage of the original strength by practicing brand extension in cyber space, or to make full use of its website brand awareness in the traditional market by manufacturing and selling normal products named after its website brand which can transform the potential value of brand equity into the real benefit in normal physical market. Just take Yahoo as an example. After achieving great success in website operation, they started to manufacture electrical products named after Yahoo, its famous online brand. However, the high brand value of those well-known portal websites also makes the brands themselves the target of rush registration and violation of trademarks. For example, some companies have rush-registered a trademark of Sina for their MP3 player. This also rings the alarm bell for Chinese websites to develop sense of protecting legitimate right to their own brand assets.

\subsection{Limitations and further research}

The limitations of current study are as follows. First, we roughly divide the 
websites into 4 categories and test 5 brands for each category respectively, while actually there are far more than 4 categories and a lot more than 5 brands for each category, such as specialized websites of search engines, news, health care, education, sports and also website brands derived from traditional brands of normal goods and services. These websites are not included in the current study. Therefore, the applicability of exiting conclusions needs to be tested in those types of websites. Second, relationships among variables in this model may vary among different users' characteristics such as access motivations and using experiences so that following studies can emphasize the possible moderated roles of those factors. Last but not least, we adopt the method of online survey to gather data which restricted the respondents to Internet users with an exclusion of general consumers who less frequently use the Internet. Since the less frequent Internet users may differ from the "netizens" in terms of website brand cognition, scholars can conduct more tests on this group of people to see if great differences can be found in the conclusion of brand equity structure in future studies, which is of great importance in improving website brand equity model and promoting brand extension of website brands further into normal market.

Acknowledgements This work is sponsored by Shanghai Pujiang Program and Scientific Research Foundation for the Returned Overseas Chinese Scholars, Education Ministry of China.

\section{References}

Aaker D A (1996). Measuring brand equity across products and markets. California Management Review, 38(3): 102-120

Aaker D A, Joachimsthaler E (2000). Brand Leadership. New York: The Free Press, 115

Berry L L (2000). Cultivating service brand equity. Journal of Academy of Marketing Science, 28(1): 128-137

Chaudhuri A, Holbrook M B (2001). The effects from brand trust and brand affect to brand performance: The role of brand loyalty. Journal of Marketing, 65: 81-93

Chen Q and Rodgers S (2006). Development of an instrument to measure website personality. Journal of Interactive Advertising, 7(1): 47-64

Cho C, Leckenby J D (1999). Interactivity as a measure of advertising effectiveness. In: Roberts M S (ed.), Proceedings of the 1999 American Academy of Advertising, Pullman, WA, 162-179

Christodoulides G, De Chernatony L (2004). Dimensionalising on and off-line brands' composite equity. Journal of Product and Brand Management, 13(3): 168-179

Christodoulides G, De Chernatony L, Furrer O, Shiu E, Abimbola T (2006). Conceptualizing and measuring the equity of online brands. Journal of Marketing Management, 22(7-8): 799-825

Coyle J R, Thorson E (2001). The effects of progressive levels of interactivity and vividness in web marketing sites. Journal of Advertising, 30(3): 65-77 
Dayal S, Landesberg H, Zeisser M (2000). Building digital brands. The McKinsey Quarterly, (2): $42-51$

Ha H Y, Perks H (2005). Effects of consumer perceptions of brand experience on the web: Brand familiarity, satisfaction and brand trust. Journal of Consumer Behavior, 4(6): 438-452

Hoffman L D, Novak T (1996). Marketing in hypermedia computer-mediated environments: Conceptual foundations. Journal of Marketing, 60: 50-68

Hoffman L D, Novak T, Yung Y F (2000). Measuring the consumer experience in online environments: A structural modeling approach. Marketing Science, 19(1): 22-42

Keller K L (1993). Conceptualizing measuring and managing consumer-based brand equity. Journal of marketing, 57: 1-22

Keller K L (2001). Building consumer-based brand equity. Marketing management, (July/August): 15-19

Liu Y P, Shrum L J (2002). What is interactivity and is it always such a good thing? Implications of definition, person, and situation for the influence of interactivity on advertising effectiveness. Journal of Advertising, 31(4): 53-64

Loiacono E, Watson R T, Goodhue D L (2002). Webqual: A measure of website quality. In: Proceedings of the American Marketing Association, (Winter): 432-438

Mackay M M (2001). Evaluation of brand equity measures: Further empirical results. Journal of Product and Brand Management, 10(1): 38-51

Naude P, Buttle F (2000). Assessing relationship quality. Industrial Marketing Management, (29): 351-361

Nicholson C Y, Sethi R (2002). The dimensions of brand web site experience. In: Proceedings of the American Marketing Association, Winter Educators. Conference: Marketing Theory and Applications, Chicago, IL, Vol. 13, 510-511

Okazaki S (2006). Excitement or sophistication? A preliminary exploration of online brand personality. International Marketing View, 23(3): 279-303

Page C, Lepkowska-White E (2002). Web equity: A framework for building consumer value in online companies. Journal of Consumer Marketing, 19(3): 231-248

Palmer J W (2002). Web site usability, design, and performance metrics. Information Systems Research, 13(2): 151-167

Rowley J (2004). Online branding. Online Information Review, 28(2): 131-138

Rowley J (2004). Online branding: The case of McDonald's. British Food Journal, 106(3): $228-237$

Shih C (1998). Conceptualizing consumer experience in cyberspace. European Journal of Marketing, 32(7/8): 655-663

Wilkie W L (1994). Consumer Behavior ( $3^{\text {rd }}$ edition). John Willey \& Sons, 275

Yoo B, Donthu N (2001). Developing and validating a multidimensional consumer-based brand equity scale. Journal of Business Research, 52: 1-14

Yoo B, Donthu N, Lee S (2000). An examination of selected marketing mix elements and brand equity. Journal of Academy of Marketing Science, 28(2): 195-211 